\title{
Polyamine Oxidation Is Indispensable for Wheat (Triticum aestivum L.) Oxidative Response and Necrotic Reactions during Leaf Rust (Puccinia triticina Eriks.) Infection
}

\author{
Marta Dmochowska-Boguta *(D), Yuliya Kloc (D) and Waclaw Orczyk (D) \\ Department of Genetic Engineering, Plant Breeding and Acclimatization Institute-National Research Institute, \\ Radzikow, 05-870 Blonie, Poland; y.kloc@ihar.edu.pl (Y.K.); w.orczyk@ihar.edu.pl (W.O.) \\ * Correspondence: m.dmochowska-boguta@ihar.edu.pl
}

check for

updates

Citation: Dmochowska-Boguta, M.; Kloc, Y.; Orczyk, W. Polyamine Oxidation Is Indispensable for Wheat (Triticum aestivum L.) Oxidative Response and Necrotic Reactions during Leaf Rust (Puccinia triticina Eriks.) Infection. Plants 2021, 10, 2787. https://doi.org/10.3390/ plants10122787

Academic Editors: Anna De Maio and Carmen Arena

Received: 30 November 2021 Accepted: 14 December 2021 Published: 16 December 2021

Publisher's Note: MDPI stays neutral with regard to jurisdictional claims in published maps and institutional affiliations.

Copyright: (c) 2021 by the authors. Licensee MDPI, Basel, Switzerland. This article is an open access article distributed under the terms and conditions of the Creative Commons Attribution (CC BY) license (https:/ / creativecommons.org/licenses/by/ $4.0 /)$.

\begin{abstract}
Hydrogen peroxide is a signal and effector molecule in the plant response to pathogen infection. Wheat resistance to Puccinia triticina Eriks. is associated with necrosis triggered by oxidative burst. We investigated which enzyme system dominated in host oxidative reaction to $P$. triticina infection. The susceptible Thatcher cultivar and isogenic lines with defined resistance genes were inoculated with $P$. triticina spores. Using diamine oxidase (DAO) and polyamine oxidase (PAO) inhibitors, accumulation of $\mathrm{H}_{2} \mathrm{O}_{2}$ was analyzed in the infection sites. Both enzymes participated in the oxidative burst during compatible and incompatible interactions. Accumulation of $\mathrm{H}_{2} \mathrm{O}_{2}$ in guard cells, i.e., the first phase of the response, depended on DAO and the role of PAO was negligible. During the second phase, the patterns of $\mathrm{H}_{2} \mathrm{O}_{2}$ accumulation in the infection sites were more complex. Accumulation of $\mathrm{H}_{2} \mathrm{O}_{2}$ during compatible interaction (Thatcher and TcLr34 line) moderately depended on DAO and the reaction of TcLr34 was stronger than that of Thatcher. Accumulation of $\mathrm{H}_{2} \mathrm{O}_{2}$ during incompatible interaction of moderately resistant plants (TcLr24, TcLr25 and TcLr29) was DAO-dependent in TcLr29, while the changes in the remaining lines were not statistically significant. A strong oxidative burst in resistant plants (TcLr9, TcLr19, TcLr26) was associated with both enzymes' activities in TcLr9 and only with DAO in TcLr19 and TcLr26. The results are discussed in relation to other host oxidative systems, necrosis, and resistance level.
\end{abstract}

Keywords: 1,12-diaminododecane; 2-bromoethylamine; brown rust; diamine oxidase; hydrogen peroxide; hypersensitive reaction; $L r$ gene; polyamine oxidase; resistance; wheat

\section{Introduction}

Localized accumulation of reactive oxygen species (ROS) known as the oxidative burst is a plant response to pathogen infection and is an important component of plant resistance. In plants, ROS production was documented for the first time by Doke [1] in potato tubers infected with Phytophthora infestans. Results published since then have documented production of different ROS molecules not only in the response to pathogen invasion [2] but also in a number of biological processes including growth, development and reaction to environmental stresses [3]. Reactive oxygen species (ROS) include singlet oxygen $\left({ }^{1} \mathrm{O}_{2}\right)$, hydroxyl radicals $\left({ }^{\bullet} \mathrm{OH}\right)$, superoxide anion $\left(\mathrm{O}^{2 \bullet-}\right)$ and hydrogen peroxide. Production of ROS, which are toxic in higher concentrations, is strictly regulated by ROSscavenging enzymes. Balance of ROS production and scavenging is maintained by complex red-ox systems [4,5]. The majority of ROS generated in response to pathogen infection is accumulated in the apoplast. Immediately after infection and recognition of the pathogen, the membrane-bound NADPH oxidases and the apoplastic peroxidases are activated and serve as the source of apoplastic ROS in the so-called oxidative response [6].

ROS are key factors in the two-phase oxidative burst and hypersensitive response in plant-pathogen interaction [7]. Hydrogen peroxide with its half-life of about $1 \mathrm{~ms}$ is the most stable of all ROS and, therefore, capable of triggering intra- and intercellular 
signaling and downstream reactions [3]. Apoplastic $\mathrm{H}_{2} \mathrm{O}_{2}$ is generated by diverse enzyme systems: plasma membrane-localized NADPH oxidases (NOX, respiratory burst oxidase homologs, RBOHs), cell wall class III peroxidases (POX), diamine oxidases (DAO) and polyamine oxidases (PAO). The enzymes DAO and PAO generate $\mathrm{H}_{2} \mathrm{O}_{2}$ by oxidation of aliphatic amines, putrescine, spermidine and spermine. Oxidation of putrescine is catalyzed by diamine copper-containing amine oxidase (DAO/CuAO), while oxidation of spermidine and spermine is catalyzed by polyamine oxidase (PAO) [8]. Both enzyme systems form a complex network and are important players in the regulation of cell and tissue differentiation and organ development. They function as regulators of programmed cell death (PCD), which is an indispensable process in both plant differentiation and the immune response [9]. Accumulation of polyamines, elevated expression of PAO- and DAO-encoding genes and increased generation of apoplastic ROS have been reported in diverse plant-pathogen systems: tobacco infected with Pseudomonas syringae pv. tabaci [10], oat infected with Puccinia coronata f. sp. avenae [11] and tobacco (N. tabacum) infected with a necrotrophic pathogen (Sclerotinia sclerotiorum) [12]. All these processes were associated with a hypersensitive response (HR): in barley after powdery mildew infection [13], in tobacco after Tobacco mosaic virus (TMV) infection [14] and in tobacco-cultured cells treated with cryptogein, which acted as an HR elicitor [15]. Compatible results of elevated accumulation of putrescine and spermine and higher expression of genes involved in polyamine metabolism were typical not only for host but also for nonhost plant-pathogen systems. The involvement of polyamine accumulation and polyamine oxidation in host HR was found in Arabidopsis thaliana infected with Pseudomonas syringae and rice infected with Magnaporthe grisea. The nonhost HR was reported in tobacco infected with Pseudomonas cichorii. Moreover, in this system, silencing of the PAO-encoding gene lowered $\mathrm{H}_{2} \mathrm{O}_{2}$ accumulation and alleviated symptoms of HR. This set of results confirmed the role of PAO in pathogen-induced oxidative burst and pathogen-triggered PCD [16] (Figure 1).

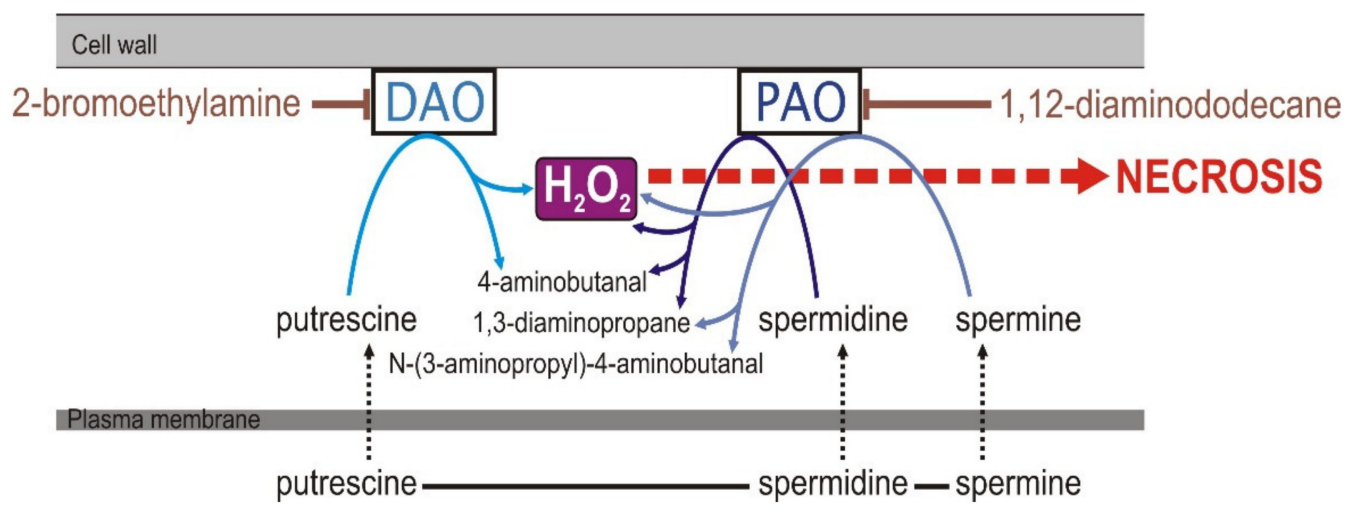

Figure 1. Generation of $\mathrm{H}_{2} \mathrm{O}_{2}$ by DAO and PAO in polyamine catabolism. Metabolic inhibitors of both enzymes and the role of $\mathrm{H}_{2} \mathrm{O}_{2}$ as a signal molecule in Programmed Cell Death and necrosis are indicated. According to modified [8,17].

In this study, the wheat cultivar Thatcher and seven near-isogenic lines containing $\mathrm{Lr}$ resistance genes (Lr9, Lr24, Lr25, Lr26, Lr29 and Lr34) were used. The Lr9 gene, transferred to wheat from Aegilops umbellulata, is located on the chromosome 6BL of wheat [18]. This gene confers highly effective resistance and, despite reports about virulent isolates, it is still an important component of wheat resistance to leaf rust [19]. The Lr19 gene, from Thinopyrum ponticum, is located on wheat chromosome 7DL [20]. This translocation also contains the Sr25 gene, which confers resistance to stem rust [21,22]. The Lr24 gene transferred from Thinopyrum ponticum is associated with Sr24 stem rust resistance [23]. The Lr25 gene, from rye Secale cereale, located on chromosome 4BS, is associated with the Pm7 powdery mildew resistance gene [24]. The Lr26 gene, also from rye, is associated with the Sr31 gene (resistance to stem rust) and with Yr9 (yellow rust resistance) [23]. Lr29 is transferred from Thinopyrum ponticum [23]. The Lr34 gene is responsible for adult plant resistance (APR) against Puccinia triticina. It has been used in wheat cultivars for 
over 50 years and still it is not broken by pathogen evolution [25-28]. Lr34 encodes an ABC transporter. The gene has been cloned but the molecular mechanism of the resistance it confers has not been elucidated. It is intriguing that Lr34 transferred to other, phylogenetically unrelated species still conferred resistance to the pathogens [29-32].

In this study, we investigated whether the oxidative burst in the wheat-leaf rust system typically associated with necrotic reactions also relies on polyamine oxidation. The results are discussed in relation to necrotic reactions and the resistance level of wheat lines.

\section{Results}

The use of DAO and PAO inhibitors allowed the determination of which of these two enzymes played a role in the production of $\mathrm{H}_{2} \mathrm{O}_{2}$ in wheat during infection of Puccinia triticina. Strong accumulation of $\mathrm{H}_{2} \mathrm{O}_{2}$ at the infection sites in the susceptible and moderately resistant plants was observed $5 \mathrm{dpi}$ (Figure $2 \mathrm{~b}-\mathrm{e}$ ), while strong accumulation of $\mathrm{H}_{2} \mathrm{O}_{2}$ in the resistant plants was 2 dpi (Figure 2f,g).
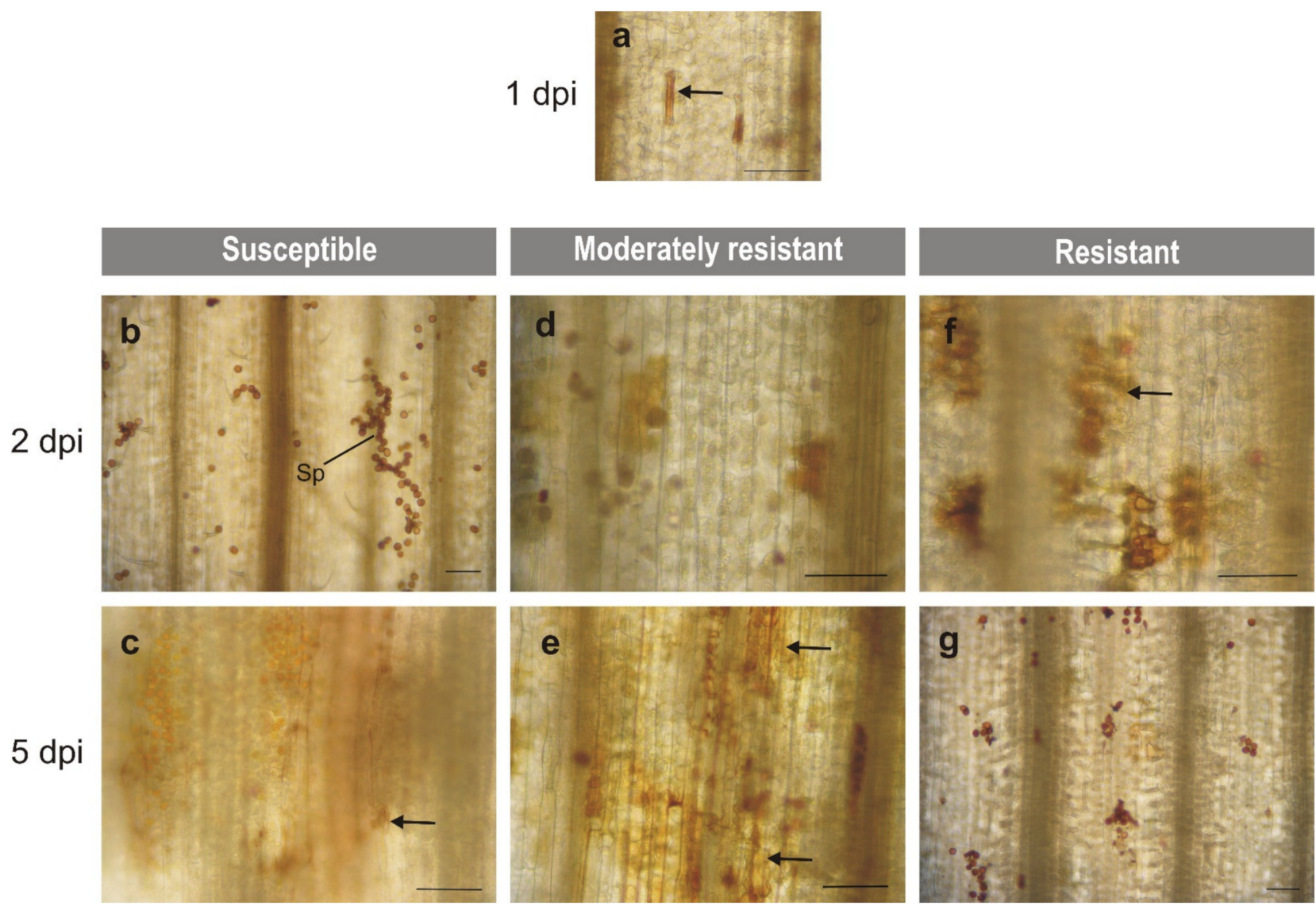

Figure 2. Microscopic localization of hydrogen peroxide accumulation in wheat leaves after inoculation with $P$. triticina spores. (a) Representative microscopic image of all tested lines 1dpi; accumulation of $\mathrm{H}_{2} \mathrm{O}_{2}$ was observed in stomata guard cells of all lines. (b,c) Representative microscopic image of susceptible Thatcher and TcLr34. (d,e) Representative microscopic image of moderately resistant: TcLr24, TcLr25 and TcLr26. (f,g) Representative microscopic image of resistant: TcLr9, TcLr19 and TcLr26. The arrows indicate $\mathrm{H}_{2} \mathrm{O}_{2}$ accumulation shown with DAB staining. Sp-spore. Bars-100 $\mu \mathrm{m}$.

In the susceptible lines (Figure 3a,b), the strongest impact in TcLr34 was 0.39 (5 dpi), while in Thatcher, it was 0.61 (5 dpi). In both cases, the strongest impact was exerted by the DAO inhibitor. In the moderately resistant lines (Figure 3c-e), the strongest impact in TcLr24 was 0.71 (5 dpi) and this was the result of PAO inhibitor treatment, while in TcLr25, it was 0.34 (4 dpi), the result of the DAO inhibitor, although the changes were not statistically significant. In TcLr29, the strongest and most statistically significant impact was 0.39 ( $4 \mathrm{dpi}$ ) for the DAO inhibitor. 


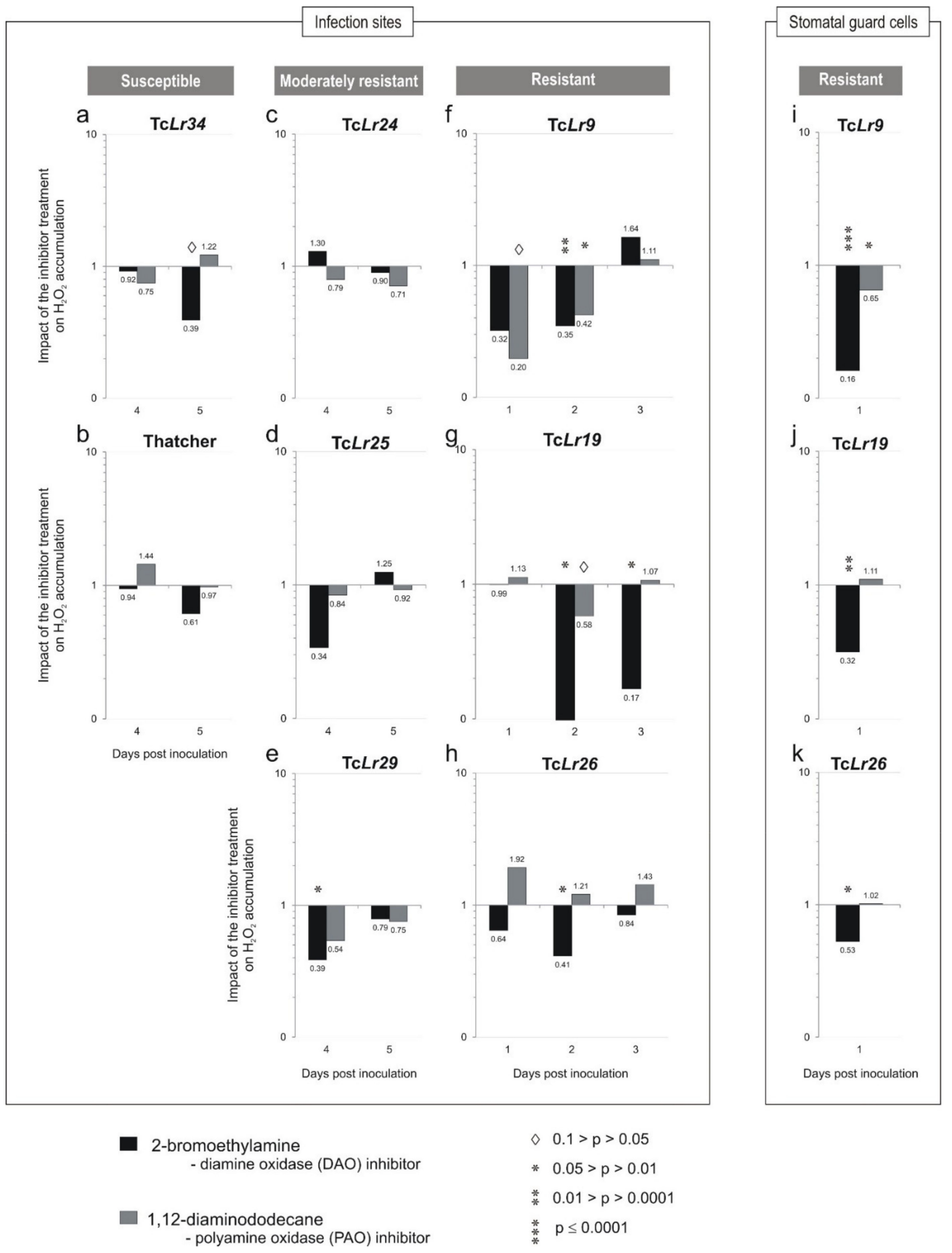

Figure 3. Impact of 2-bromorthylamine, a diamine oxidase (DAO) inhibitor, and 1,12-diaminododecane, a polyamine oxidase (PAO) inhibitor on $\mathrm{H}_{2} \mathrm{O}_{2}$ accumulation in the infection sites (a-h) and stomatal guard cells (i-k). Leaves of wheat cultivar Thatcher and isogenic lines TcLr9, TcLr19, TcLr24, TcLr25, TcLr26, TcLr29, and TcLr34 were inoculated with leaf rust spores, infiltrated with inhibitors, and stained with DAB and calcofluor white. The results are presented on a graph with a logarithmic scale, where a value of 1 indicates zero impact (control plants). Values above 1 indicate higher impact of the inhibitor on $\mathrm{H}_{2} \mathrm{O}_{2}$ accumulation, while values below 1 indicate lower impact than in the control. Statistical significance was calculated using the ANOVA test and the LSD post hoc test (STATISTICA 10, StatSoft). 
In the resistant lines (Figure $3 \mathrm{f}-\mathrm{h}$ ), the strongest and most statistically significant impact in TcLr9 was 0.35 (2dpi) for the DAO inhibitor, and 0.42 (2 dpi) for the PAO inhibitor. The strongest and most statistically significant impact in TcLr19 was 0.004 (2 dpi) and, in TcLr26, 0.41 (2 dpi). In these lines, the impact of the DAO inhibitor dominated; however, in the TcLr9, the inhibitors of both DAO and PAO enzymes showed a strong impact (Figure 3f).

On the first day after inoculation, $\mathrm{H}_{2} \mathrm{O}_{2}$ was accumulated in stomata guard cells in all tested genotypes, indicating that the response was not specific to one particular type of interaction. The impact of inhibitors was scored in the resistant lines (Figure 3i-k). The strongest and most statistically significant impact on $\mathrm{H}_{2} \mathrm{O}_{2}$ accumulation in stomatal guard cells in TcLr9 was 0.16, in TcLr19-0.32, and in TcLr26-0.53. In these lines, the DAO inhibitor effect strongly prevailed.

\section{Discussion}

Accumulation of hydrogen peroxide in the infection site plays an important role in plant defense. In this study, we investigated whether the oxidative burst and necrotic response in wheat infected with leaf rust relied upon the activities of two polyamine oxidation enzymes, and whether these activities depended on the genetic background of wheat lines. The roles of the enzymes were assessed in leaves inoculated with P. triticina and infiltrated with the specific inhibitors of the tested enzymes, 2-bromoethylamine (DAO inhibitor) and 1,12-diaminododecane (PAO inhibitor). The results indicated that out of the two tested enzymes, DAO activity prevailed in the oxidative response of wheat to P. triticina infection. However, the pattern of this involvement varied in lines with different Lr resistance genes.

In susceptible plants (cv. Thatcher, TcLr34), an oxidative response was observed from 4 to $7 \mathrm{dpi}$ [33]. This coincided with completing the pathogen life cycle and was associated with the development of uredinia, as reported by Orczyk et al. [33]. In these lines, accumulation of $\mathrm{H}_{2} \mathrm{O}_{2}$ was significantly alleviated 5 dpi by 2-bromoethylamine indicating the predominant role of DAO in the oxidative response of susceptible plants. In these plants, NADPH oxidase and class III peroxidases were also involved in the accumulation of $\mathrm{H}_{2} \mathrm{O}_{2}$ [34] (Figure S1 in Supplementary Materials). In moderately resistant lines (TcLr24, TcLr25 and TcLr29), accumulation of $\mathrm{H}_{2} \mathrm{O}_{2}$ steadily increased from 1 to $8 \mathrm{dpi}$ [33] and was associated with a necrosis reaction (Figure 4e,f) [33]. However, neither of them was sufficient to fully arrest pathogen growth and uredinia formation. The results indicated participation of both enzymes in the oxidative response; PAO activity prevailed in the response of TcLr24 (Figure 3c), DAO in TcLr25 (Figure 3d) and both enzymes in the response of TcLr29 (Figure 3e); however, only the changes observed in TcLr29 were statistically significant. Additionally, as previously reported by DmochowskaBoguta et al. [34], the oxidative response in these lines involved type III peroxidases (POX) in TcLr24 and NADPH oxidases (NOX) along with POX in TcLr25 and TcLr29 (Figure S1 in Supplementary Materials).

In resistant lines (TcLr9, TcLr19 and TcLr26), the strong oxidative response showed a typical biphasic pattern. The first phase, i.e., accumulation of $\mathrm{H}_{2} \mathrm{O}_{2}$ in stomata guard cells with appressoria (Figures $2 \mathrm{a}$ and $4 \mathrm{a}$ ), was probably induced by pressure generated by appressoria and was observed shortly after inoculation (1 dpi) in susceptible as well as resistant plants [33]. Here, we investigated the effect of the inhibitors on $\mathrm{H}_{2} \mathrm{O}_{2}$ accumulation in guard cells only in resistant plants. The reaction was strongly affected in plants treated with the DAO inhibitor (Figure 3i-k) indicating that, out of the two tested enzymes, the DAO activity prevailed in the generation of $\mathrm{H}_{2} \mathrm{O}_{2}$ in guard cells. Our earlier results showed that NOX and POX [34] (Figure S1 in Supplementary Materials) were involved in this phase of oxidative burst. The present results extend the knowledge and show that the first step of $\mathrm{H}_{2} \mathrm{O}_{2}$ accumulation in guard cells of infected wheat involves DAO and POX activities in all tested lines and, additionally, NOX activity in highly resistant TcLr26 (Figure S1 in Supplementary Materials). The second phase of the oxidative burst is the 
generation of ROS localized in cells directly affected by germinating spores [33]. In the resistant lines, it was observed as a strong oxidative reaction associated with rapid necrosis (Figure $4 \mathrm{~g}$,h). Maximum accumulation of $\mathrm{H}_{2} \mathrm{O}_{2}$ observed $2 \mathrm{dpi}$ was steadily lowered in the subsequent days [33]. The oxidative response in this phase was strongly inhibited by 2-bromoethylamine (DAO inhibitor) 1 and $2 \mathrm{dpi}$ in all tested lines.
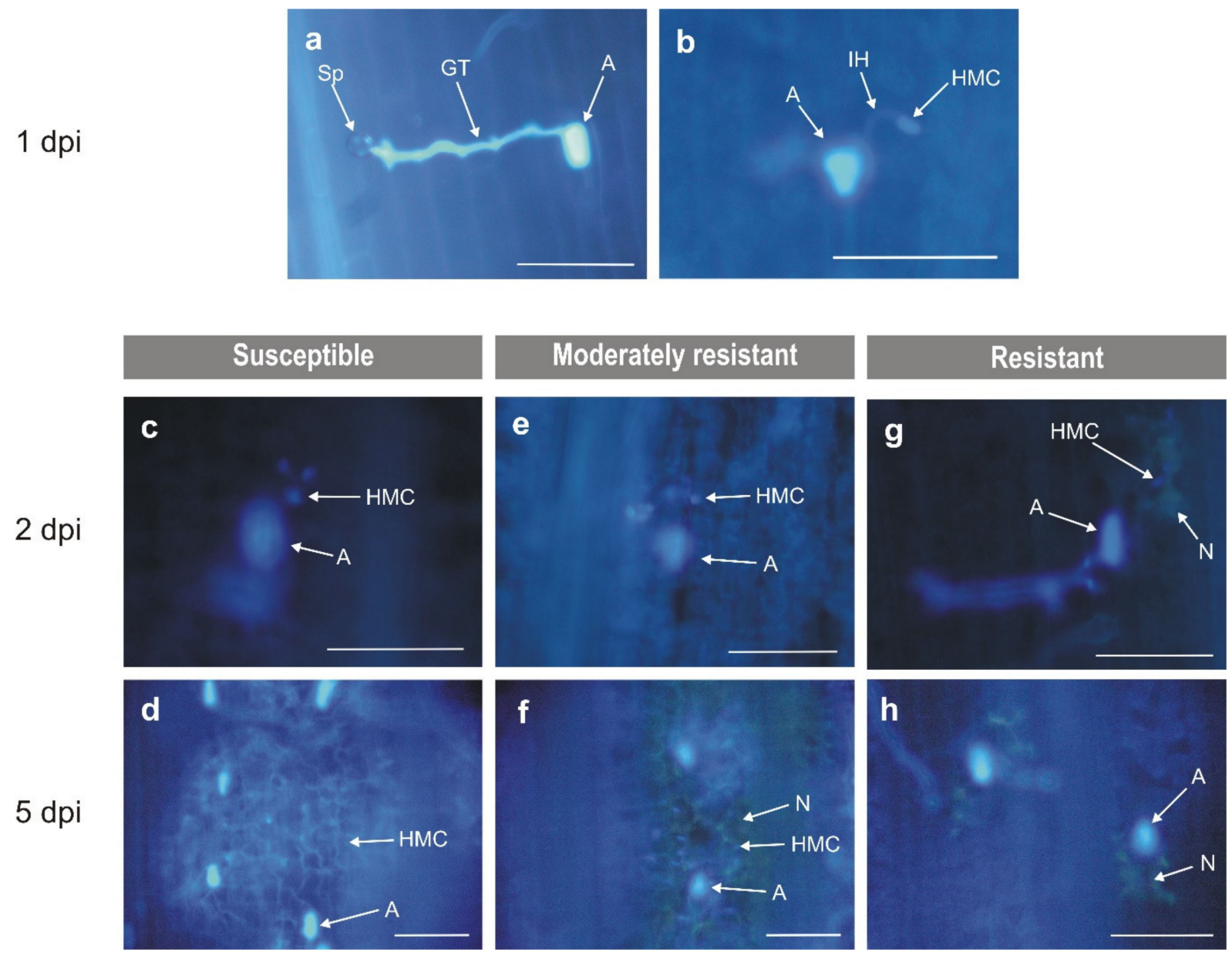

Figure 4. Microscopic observations of plant-pathogen interactions. The observations 1 day post-inoculation were the same for all lines. (a,b) Representative microscopic image of all tested lines 1dpi. (c,d) Representative microscopic image of susceptible Thatcher and TcLr34. (e,f) Representative microscopic image of moderately resistant TcLr24, TcLr25 and TcLr26. (g,h) Representative microscopic image of resistant TcLr9, TcLr19 and TcLr26. Sp—spore; GT—germ tube; A—appressorium; $\mathrm{IH}$-infection hyphae; HMC—haustorium mother cell; N—necrosis. Bars-100 $\mu \mathrm{m}$.

Additionally, in TcLr9, the reaction was also alleviated by 1,12-diaminododecane, indicating the role of PAO activity in this reaction. This set of results complements our earlier reports [34] (Figure S1 in Supplementary Materials) that class III peroxidases and NADPH oxidases were significant sources of ROS in resistant lines after P. triticina infection. All four enzyme systems are involved in the oxidative burst in wheat isogenic lines with an $L r$ resistance gene upon inoculation with $P$. triticina. In this study, the inhibitors of the enzymes were used, not a directly measured activity of the enzymes. The former would be important to confirm the role of the enzymes in oxidative burst, necrosis and plant immunity.

Elevated activities of DAO and PAO in response to pathogen infection have been found in diverse plant-pathogen systems. Asthir et al. [35] reported increased activities of both oxidases in wheat inoculated with Puccinia striiformis (stripe rust) and the reaction was observed in resistant and susceptible genotypes. A similar oxidative response was noted in barley inoculated with Blumeria graminis (powdery mildew). The reaction, which included 
the accumulation of polyamines and upregulation of DAO oxidases, was observed in both susceptible and resistant plants, but it was stronger in the resistant genotypes [36]. In the same system, the hypersensitive response to powdery mildew was associated with increased levels of free and conjugated forms of polyamines and the elevated activities of both enzymes DAO and PAO. In this system, polyamine accumulation and polyamine oxidation were associated with HR-related resistance [13]. The maize response to infection with the biotrophic fungus Ustilago maydis included elevated activity of PAO followed by accumulation of $\mathrm{H}_{2} \mathrm{O}_{2}$ and cell wall lignification [37]. Exogenous spermine, a substrate of PAO, applied to tomato and Arabidopsis thaliana induced resistance to the necrotrophic pathogen Botrytis cinerea. Combined spermine treatment and pathogen inoculation increased the expression of $P A O$ genes, leading to $\mathrm{H}_{2} \mathrm{O}_{2}$ accumulation, a hypersensitive response, and pathogen elimination [38]. Yoda et al. [14] found that polyamine-dependent oxidative burst was a key factor of resistance to Tobacco mosaic virus (TMV). They found that the rate of hypersensitive cell death in tobacco leaves infected with TMV was directly associated with synthesis and oxidation of polyamines, and accumulation of $\mathrm{H}_{2} \mathrm{O}_{2}$. Another article from the same laboratory [16] stated that polyamines were the source of $\mathrm{H}_{2} \mathrm{O}_{2}$ in both host and nonhost HRs in higher plants. The authors reported accumulation of polyamines, increased PAO expression, accumulation of $\mathrm{H}_{2} \mathrm{O}_{2}$ and $\mathrm{HR}$ reaction in the tobacco response to the non-host pathogen Pseudomonas cichorii. Similar reactions in host systems were found in Arabidopsis thaliana infected with Pseudomonas syringae and rice infected with Magnaporthe grisea. As was also reported [39], in the case of Arabidopsis, hypersensitive response to the non-host Pseudomonas syringae pv. tomato, the infection was significantly but not completely blocked by NOX inhibitors, which indicated a role of this oxidative system. Different levels of DAO and PAO activity were observed in barley infected with Puccinia strifformis f. sp. hordei, depending on the cultivar and isolate [40].

The results presented here show that both DAO and PAO play important roles in the wheat oxidative response to $P$. triticina infection. Participation of the enzymes in the production of hydrogen peroxide was different depending on the $L r$ resistance genes in the wheat line. The general trend showed that the stronger the resistance, the stronger the involvement of PAO and DAO in oxidative burst. Combining the results with our previous findings in the same plant-pathogen system [34] (Figure S1 in Supplementary Materials), we can state that the four systems-POX, NOX, DAO and PAO_-participated in the wheat oxidative response to P. triticina, although the role of NOX was the smallest. In the susceptible and moderately resistant plants, DAO dominated, but only in TcLr29 and TcLr34 were the changes statistically significant. In resistant plants, an early oxidative response strongly depended on DAO and, in the TcLr9 line, also on PAO.

\section{Materials and Methods}

\subsection{Plant Materials}

Plant material was the wheat cultivar Thatcher and isogenic lines with $L r$ genes TcLr9, TcLr19, TcLr24, TcLr25, TcLr26, TcLr29 and TcLr34, and fungus material was a Puccinia triticina isolate. The selected lines were previously characterized by the interaction with the $P$. triticina isolate used [33]. These lines were selected and classified into three groups: susceptible-Thatcher (infection type 4) and TcLr34 (4); moderately resistant-TcLr24 (1), TcLr25 (2) and TcLr29 (1); and resistant-TcLr9 (0), TcLr19 (0;) and TcLr26 (0). Plants were grown in a growth chamber at $22{ }^{\circ} \mathrm{C}$ and $16 \mathrm{~h}$ photoperiod. Seven-day-old seedlings were inoculated with $P$. triticina spores $(0.5 \mathrm{mg} / \mathrm{mL}$ water with Tween 20$)$ and placed in the dark at $16{ }^{\circ} \mathrm{C}$ and $100 \%$ humidity for $24 \mathrm{~h}$. After this time, the plants were transferred back to the growth chamber.

\subsection{DAO and PAO Inhibitor Treatment and Leaf Staining with Calcofluor White and DAB}

Wheat leaves were inoculated with $P$. triticina spores and infiltrated with the inhibitors. The infiltration time was chosen based on our previous results [33]. It was 4 and 5 dpi for the susceptible and the moderately resistant lines [33], and 1, 2 and 3 dpi 
for the resistant lines [33]. Intact leaves were infiltrated, using sponge corks and clamps, with 2-bromoethylamine (DAO inhibitor) $100 \mathrm{mM}$ in $15 \mathrm{mM} \mathrm{NaPi} \mathrm{pH} 6.5$ [41] and 1,12diaminododecane (PAO inhibitor) at a concentration of $200 \mu \mathrm{M}$ in the same buffer [42]. The leaves infiltrated with buffers (mock) served as controls. An infiltrated leaf fragment of approximately $2 \mathrm{~cm}$ long was marked. After $1 \mathrm{~h}$, leaf samples were cut, collected and stained with 3'3-diaminobenzidine-tetrahydrochloride (DAB) for hydrogen peroxide and calcofluor white to visualize pathogen structures.

Leaf samples were stained in $\mathrm{DAB} 1 \mathrm{mg} / \mathrm{mL} \mathrm{pH} 3.8$ during $4 \mathrm{~h}$ in the dark $[43,44]$ and destained in ethanol:chloroform (4:1 v/v) with trichloroacetic acid $0.15 \%$ for $24 \mathrm{~h} \mathrm{[45].} \mathrm{DAB}$ on contact with hydrogen peroxide turns into a brown precipitate, which was observed under a light microscope.

For calcofluor white staining, the samples were washed twice in ethanol $50 \%$, twice in $\mathrm{NaOH} 0.05 \mathrm{M}$, three times in water, once in Tris- $\mathrm{HCl} 0.1 \mathrm{M} \mathrm{pH} 8.5$ and stained in calcofluor white $3.5 \mathrm{mg} / \mathrm{mL}$ (Fluorescent brightener 28, Sigma F-6259, Milwaukee, WI, USA) in Tris- $\mathrm{HCl} 0.1 \mathrm{M} \mathrm{pH}$ 9.0. The samples were washed once in water and stored in glycerol 25\% with $0.1 \%$ lactophenol (phenol $1 \mathrm{~g} / \mathrm{mL}$ :glycerol:lactic acid, 1:1:1, v:v:v) [46]. The infection sites were observed under a fluorescence microscope (Nikon Diaphot, Aizu, Japan, epifluorescence optics with excitation 340-380 nm, barrier filter $420 \mathrm{~nm}$ and dichroic mirror $400 \mathrm{~nm}$ ). The pathogen structures stained with calcofluor white were blue-white. At least 30 infection sites were scored in triplicate biological repetitions per single experimental time-point.

The total numbers of infection sites and DAB-stained (i.e., $\mathrm{H}_{2} \mathrm{O}_{2}$ accumulating) sites were counted, and the percentage of DAB-stained sites was calculated in the inhibitortreated and in the control plants. The results, shown as the impact of the inhibitor, were calculated according to the following formulas:

$$
\begin{aligned}
\% \mathrm{DAB}_{\text {control }}= & \frac{\text { number of infection sites stained with } \mathrm{DAB}}{\text { number of all infection sites }} \times 100 \% \\
\% \mathrm{DAB}_{\text {inhibitor }}= & \frac{\text { number of infection sites stained with DAB after inhibitor treatment }}{\text { number of all infection sites after inhibitor treatment }} \\
& \times 100 \%
\end{aligned}
$$

The ANOVA test and the least significant difference (LSD) post hoc test (STATISTICA 10 , StatSoft) were used for the statistical analysis of $\% \mathrm{DAB}$ inhibitor and $\% \mathrm{DAB} \mathrm{B}_{\text {control }}$.

Supplementary Materials: The following are available online at https:/ /www.mdpi.com/article/10 $.3390 /$ plants10122787/s1, Figure S1: The impact of NADPH oxidase inhibitor and class III peroxidase inhibitor in TcLr19, TcLr29 and TcLr34 lines after inoculation with leaf rust spores.

Author Contributions: Conceptualization, M.D.-B. and W.O.; methodology, M.D.-B.; formal analysis, M.D.-B.; investigation, M.D.-B. and Y.K.; resources, M.D.-B.; writing-original draft preparation, M.D.-B. and W.O.; writing-review and editing, M.D.-B., Y.K. and W.O.; visualization, M.D.-B.; supervision, M.D.-B. and W.O.; project administration, M.D.-B. and W.O.; funding acquisition, M.D.-B. and W.O. All authors have read and agreed to the published version of the manuscript.

Funding: This research was funded by Statutory project nr 1-3-00-3-01 (MD-B) and National Research Centre nr UMO-2019/35/B/NZ9/00323 (WO).

Data Availability Statement: The data presented in the current study are available from the corresponding authors on reasonable request.

Conflicts of Interest: The authors declare no conflict of interest. The funders had no role in the design of the study; in the collection, analyses, or interpretation of data; in the writing of the manuscript, or in the decision to publish the results. 


\section{References}

1. Doke, N. Generation of Superoxide Anion by Potato-Tuber Protoplasts during the Hypersensitive Response to Hyphal Wall Components of Phytophthora infestans and Specific-Inhibition of the Reaction by Suppressors of Hypersensitivity. Physiol. Plant Pathol. 1983, 23, 359-367. [CrossRef]

2. Qi, J.; Wang, J.; Gong, Z.; Zhou, J.M. Apoplastic ROS signaling in plant immunity. Curr. Opin. Plant Biol. 2017, 38, 92-100. [CrossRef]

3. Baxter, A.; Mittler, R.; Suzuki, N. ROS as key players in plant stress signalling. J. Exp. Bot. 2014, 65, 1229-1240. [CrossRef]

4. Miller, G.; Suzuki, N.; Ciftci-Yilmaz, S.; Mittler, R. Reactive oxygen species homeostasis and signalling during drought and salinity stresses. Plant Cell Environ. 2010, 33, 453-467. [CrossRef]

5. Foyer, C.H.; Noctor, G. Redox homeostasis and antioxidant signaling: A metabolic interface between stress perception and physiological responses. Plant Cell 2005, 17, 1866-1875. [CrossRef]

6. Kadota, Y.; Shirasu, K.; Zipfel, C. Regulation of the NADPH Oxidase RBOHD During Plant Immunity. Plant Cell Physiol. 2015, 56, 1472-1480. [CrossRef]

7. De Pinto, M.C.; Locato, V.; De Gara, L. Redox regulation in plant programmed cell death. Plant Cell Environ. 2012, 35, $234-244$. [CrossRef]

8. Kusano, T.; Yamaguchi, K.; Berberich, T.; Takahashi, Y. Advances in polyamine research in 2007. J. Plant Res. 2007, 120, 345-350. [CrossRef]

9. Tavladoraki, P.; Cona, A.; Angelini, R. Copper-Containing Amine Oxidases and FAD-Dependent Polyamine Oxidases Are Key Players in Plant Tissue Differentiation and Organ Development. Front. Plant. Sci. 2016, 7, 824. [CrossRef]

10. Moschou, P.N.; Sarris, P.F.; Skandalis, N.; Andriopoulou, A.H.; Paschalidis, K.A.; Panopoulos, N.J.; Roubelakis-Angelakis, K.A. Engineered polyamine catabolism preinduces tolerance of tobacco to bacteria and oomycetes. Plant Physiol. 2009, 149, 1970-1981. [CrossRef]

11. Montilla-Bascon, G.; Rubiales, D.; Altabella, T.; Prats, E. Free polyamine and polyamine regulation during pre-penetration and penetration resistance events in oat against crown rust (Puccinia coronata f. sp. avenae). Plant Pathol. 2015, 65, 392-401. [CrossRef]

12. Marina, M.; Maiale, S.J.; Rossi, F.R.; Romero, M.F.; Rivas, E.I.; Garriz, A.; Ruiz, O.A.; Pieckenstain, F.L. Apoplastic polyamine oxidation plays different roles in local responses of tobacco to infection by the necrotrophic fungus Sclerotinia sclerotiorum and the biotrophic bacterium Pseudomonas viridiflava. Plant Physiol. 2008, 147, 2164-2178. [CrossRef]

13. Cowley, T.; Walters, D.R. Polyamine metabolism in barley reacting hypersensitively to the powdery mildew fungus Blumeria graminisf. sp. hordei. Plant Cell Environ. 2002, 25, 461-468. [CrossRef]

14. Yoda, H.; Yamaguchi, Y.; Sano, H. Induction of hypersensitive cell death by hydrogen peroxide produced through polyamine degradation in tobacco plants. Plant Physiol. 2003, 132, 1973-1981. [CrossRef]

15. Yoda, H.; Hiroi, Y.; Sano, H. Polyamine oxidase is one of the key elements for oxidative burst to induce programmed cell death in tobacco cultured cells. Plant Physiol. 2006, 142, 193-206. [CrossRef]

16. Yoda, H.; Fujimura, K.; Takahashi, H.; Munemura, I.; Uchimiya, H.; Sano, H. Polyamines as a common source of hydrogen peroxide in host- and nonhost hypersensitive response during pathogen infection. Plant Mol. Biol. 2009, 70, 103-112. [CrossRef]

17. Gupta, K.; Sengupta, A.; Chakraborty, M.; Gupta, B. Hydrogen Peroxide and Polyamines Act as Double Edged Swords in Plant Abiotic Stress Responses. Front. Plant. Sci. 2016, 7, 1343. [CrossRef]

18. Sears, E.R. The transfer of leaf-rust resistance from Aegilops umbellulata to wheat. In Proceedings of the Brookhaven Symposia in Biology 1956, Brookhaven, GA, USA, 21-23 May 1956; Associates Universities, Inc.: Upton, NY, USA, 1956; pp. 1-22.

19. Nocente, F.; Gazza, L.; Pasquini, M. Evaluation of leaf rust resistance genes Lr1, Lr9, Lr24, Lr47 and their introgression into common wheat cultivars by marker-assisted selection. Euphytica 2007, 155, 329-336. [CrossRef]

20. Sarma, D.; Knott, D.R. The transfer of leaf-rust resistance from Agropyron to Triticum by irradiation. Can. J. Genet. Cytol. 1966, 8, 137-143. [CrossRef]

21. Reynolds, M.P.; Calderini, D.F.; Condon, A.G.; Rajaram, S. Physiological basis of yield gains in wheat associated with the Lr19 translocation from Agropyron elongatum. In Wheat in a Global Environment; Springer: Berlin/Heidelberg, Germany, 2001; Volume 9, pp. 345-351.

22. Monneveux, P.; Reynolds, M.P.; Aguilar, J.G.; Singh, R.P. Effects of the 7DL.7Ag translocation from Lophopyrum elongatum on wheat yield and related morphophysiological traits under different environments. Plant Breed. 2003, 122, 379-384. [CrossRef]

23. McIntosh, R.A.; Wellings, C.R.; Park, R.F. Wheat Rusts: An Atlas of Resistance Genes; CSIRO: Canberra, Australia, 1995.

24. Driscoll, C.J.; Anderson, L.M. Cytogenetic Studies of Transec-A Wheat-Rye Translocation Line. Can. J. Genet. Cytol. 1967, 9, 375-380. [CrossRef]

25. Feuillet, C.; Travella, S.; Stein, N.; Albar, L.; Nublat, A.; Keller, B. Map-based isolation of the leaf rust disease resistance gene Lr10 from the hexaploid wheat (Triticum aestivum L.) genome. Proc. Natl. Acad. Sci. USA 2003, 100, 15253-15258. [CrossRef] [PubMed]

26. Huang, L.; Brooks, S.A.; Li, W.L.; Fellers, J.P.; Trick, H.N.; Gill, B.S. Map-based cloning of leaf rust resistance gene Lr21 from the large and polyploid genome of bread wheat. Genetics 2003, 164, 655-664. [CrossRef] [PubMed]

27. Cloutier, S.; McCallum, B.D.; Loutre, C.; Banks, T.W.; Wicker, T.; Feuillet, C.; Keller, B.; Jordan, M.C. Leaf rust resistance gene Lr1, isolated from bread wheat (Triticum aestivum L.) is a member of the large psr567 gene family. Plant Mol. Biol. 2007, 65, 93-106. [CrossRef] 
28. Krattinger, S.G.; Lagudah, E.S.; Spielmeyer, W.; Singh, R.P.; Huerta-Espino, J.; McFadden, H.; Bossolini, E.; Selter, L.L.; Keller, B. A Putative ABC Transporter Confers Durable Resistance to Multiple Fungal Pathogens in Wheat. Science 2009, 323, $1360-1363$. [CrossRef]

29. Rinaldo, A.; Gilbert, B.; Boni, R.; Krattinger, S.G.; Singh, D.; Park, R.F.; Lagudah, E.; Ayliffe, M. The Lr34 adult plant rust resistance gene provides seedling resistance in durum wheat without senescence. Plant Biotechnol. J. 2017, 15, 894-905. [CrossRef]

30. Schnippenkoetter, W.; Lo, C.; Liu, G.; Dibley, K.; Chan, W.L.; White, J.; Milne, R.; Zwart, A.; Kwong, E.; Keller, B.; et al. The wheat Lr34 multipathogen resistance gene confers resistance to anthracnose and rust in sorghum. Plant Biotechnol. J. 2017, 15, 1387-1396. [CrossRef]

31. Sucher, J.; Boni, R.; Yang, P.; Rogowsky, P.; Buchner, H.; Kastner, C.; Kumlehn, J.; Krattinger, S.G.; Keller, B. The durable wheat disease resistance gene Lr34 confers common rust and northern corn leaf blight resistance in maize. Plant Biotechnol. J. 2017, 15, 489-496. [CrossRef]

32. Krattinger, S.G.; Sucher, J.; Selter, L.L.; Chauhan, H.; Zhou, B.; Tang, M.; Upadhyaya, N.M.; Mieulet, D.; Guiderdoni, E.; Weidenbach, D.; et al. The wheat durable, multipathogen resistance gene Lr34 confers partial blast resistance in rice. Plant Biotechnol. J. 2016, 14, 1261-1268. [CrossRef]

33. Orczyk, W.; Dmochowska-Boguta, M.; Czembor, H.J.; Nadolska-Orczyk, A. Spatiotemporal patterns of oxidative burst and micronecrosis in resistance of wheat to brown rust infection. Plant Pathol. 2010, 59, 567-575. [CrossRef]

34. Dmochowska-Boguta, M.; Nadolska-Orczyk, A.; Orczyk, W. Roles of peroxidases and NADPH oxidases in the oxidative response of wheat (Triticum aestivum) to brown rust (Puccinia triticina) infection. Plant Pathol. 2013, 62, 993-1002. [CrossRef]

35. Asthir, B.; Koundal, A.; Bains, N.S.; Mann, S.K. Stimulation of antioxidative enzymes and polyamines during stripe rust disease of wheat. Biol. Plant. 2010, 54, 329-333. [CrossRef]

36. Asthir, B.; Spoor, W.; Duffus, C.M. Involvement of polyamines, diamine oxidase and polyamine oxidase in resistance of barley to Blumeria graminis f. sp. hordei. Euphytica 2004, 136, 307-312. [CrossRef]

37. Rodriguez-Kessler, M.; Ruiz, O.A.; Maiale, S.; Ruiz-Herrera, J.; Jimenez-Bremont, J.F. Polyamine metabolism in maize tumors induced by Ustilago maydis. Plant Physiol. Biochem. 2008, 46, 805-814. [CrossRef]

38. Seifi, H.S.; Zarei, A.; Hsiang, T.; Shelp, B.J. Spermine Is a Potent Plant Defense Activator Against Gray Mold Disease on Solanum lycopersicum, Phaseolus vulgaris, and Arabidopsis thaliana. Phytopathology 2019, 109, 1367-1377. [CrossRef]

39. Grant, M.; Brown, I.; Adams, S.; Knight, M.; Ainslie, A.; Mansfield, J. The RPM1 plant disease resistance gene facilitates a rapid and sustained increase in cytosolic calcium that is necessary for the oxidative burst and hypersensitive cell death. Plant J. 2000, 23, 441-450. [CrossRef]

40. Singla, P.; Bhardwaj, R.D.; Kaur, S.; Kaur, J.; Grewal, S.K. Metabolic adjustments during compatible interaction between barley genotypes and stripe rust pathogen. Plant Physiol. Biochem. 2020, 147, 295-302. [CrossRef]

41. Rea, G.; Metoui, O.; Infantino, A.; Federico, R.; Angelini, R. Copper amine oxidase expression in defense responses to wounding and Ascochyta rabiei invasion. Plant Physiol. 2002, 128, 865-875. [CrossRef]

42. Bianchi, M.; Polticelli, F.; Ascenzi, P.; Botta, M.; Federico, R.; Mariottini, P.; Cona, A. Inhibition of polyamine and spermine oxidases by polyamine analogues. FEBS J. 2006, 273, 1115-1123. [CrossRef]

43. Tada, Y.; Mori, T.; Shinogi, T.; Yao, N.; Takahashi, S.; Betsuyaku, S.; Sakamoto, M.; Park, P.; Nakayashiki, H.; Tosa, Y.; et al. Nitric oxide and reactive oxygen species do not elicit hypersensitive cell death but induce apoptosis in the adjacent cells during the defense response of oat. Mol. Plant-Microbe Interact. 2004, 17, 245-253. [CrossRef]

44. Wang, C.-F.; Huang, L.-L.; Buchenauer, H.; Han, Q.-M.; Zhang, H.-C.; Kang, Z.-S. Histochemical studies on the accumulation of reactive oxygen species $\left(\mathrm{O}^{2-}\right.$ and $\left.\mathrm{H}_{2} \mathrm{O}_{2}\right)$ in the incompatible and compatible interaction of wheat-Puccinia striiformis f. sp. tritici. Physiol. Mol. Plant Pathol. 2007, 71, 230-239. [CrossRef]

45. Schweizer, P. Tissue-specific expression of a defence-related peroxidase in transgenic wheat potentiates cell death in pathogenattacked leaf epidermis. Mol. Plant Pathol. 2008, 9, 45-57. [CrossRef]

46. Bender, C.M.; Pretorius, Z.A.; Kloppers, F.J.; Spies, J.J. Histopathology of leaf rust infection and development in wheat genotypes containing Lr12 and Lr13. J. Phytopathol. 2000, 148, 65-76. [CrossRef] 